\title{
INSTRUMEN TES KEBUGARAN JASMANI UNTUK ANAK USIA 10-12 TAHUN
}

\author{
Wahyu Indra Bayu', Waluyo², Ahmad Richard Victorian², Al Ikhsan², Yoga Apriyanto ${ }^{2}$ \\ 'Universitas Sriwijaya, Program Studi Pendidikan Olahraga, Palembang, Indonesia \\ Universitas Sriwijaya, Program Studi Pendididkan Jasmani dan Kesehatan, Palembang, \\ Indonesia
}

wahyu.indra@fkip.unsri.ac.id, waluyo@fkip.unsri.ac.id, richardvictorian@fkip.unsri.ac.id, $\underline{\text { Ikhsanalfatih511@gmail.com, yogaapriyanto73@gmail.com }}$

\begin{abstract}
The purpose of this study was to determine physical fitness measurement instruments for children aged 10-12 years. This is the average age of children who go to school at the primary level in grades 4-6. This type of research is a survey method with percentage descriptive data analysis techniques. Purposive accidental sampling was used in this study. Respondents involved in this study were 128 respondents consisting of 19 respondents who were lecturers in the field of sports and 109 respondents were teachers of PESH at elementary school. The results of the study show that the measuring instruments for health-related physical fitness that can be applied to most elementary schools by taking into account the condition of the facilities and infrastructure are weight, height, and body mass index (body composition), 20-meter multi-stage shuttle run (cardiorespiratory endurance), sit-and-reach test (flexibility), pushup (muscle endurance), and maximal handgrip strength test (muscle strength).
\end{abstract}

Keywords: health-related physical fitness, 10-12 year old, measurement.

\begin{abstract}
Abstrak
Tujuan penelitian ini adalah untuk menentukan instrumen pengukuran kebugaran jasmani pada anak usia 10-12 tahun. Usia tersebut rata-rata anak yang sekolah pada tingkat dasar kelas 4-6. Jenis penelitian yaitu metode survei dengan teknik analisis data deskriptif persentase. Purposive accidental sampling digunakan dalam penelitian ini. Responden yang terlibat pada penelitian ini adalah 128 responden yang terdiri dari 19 responden adalah dosen dalam bidang keolahragaan dan 109 responden adalah guru PJOK tingkat SD. Hasil penelitian bahwa alat ukur untuk kebugaran jasmani yang berkaitan dengan Kesehatan yang dapat diterapkan pada sebagian besar sekolah dasar dengan memperhatikan kondisi sarana dan prasarana adalah weight, height, and body mass index (komposisi tubuh), 20-meter multi-stage shuttle run (daya tahan kardiorespirasi), sit-and-reach test (kelentukan), push-ups (daya tahan otot), dan maximal handgrip strength test (kekuatan otot).
\end{abstract}

Kata kunci: kebugaran jasmani, kesehatan, 10-12 tahun, pengukuran.

\section{PENDAHULUAN}

Istilah physical fitness mempunyai penerjemahan yang beragam, selain diterjemahkan 
P-ISSN 2505-5651

E-ISSN 2579-5910

sebagai kebugaran jasmani, dapat diterjemahkan dengan istilah-istilah lain misalnya: kesegaran jasmani, kesanggupan jasmani, dan kesamaptaan jasmani. Syarat anatomis dan fisiologi harus terpenuhi bila ingin mendapatkan kebugaran jasmani yang baik untuk melakukan aktivitas fisik sehari-hari. Kebugaran jasmani adalah indikator penting yang harus dimiliki oleh setiap manusia agar dapat beraktivitas dengan maksimal sehingga dapat memberikan hasil optimal dalam segala aktivitas.

Tidak akan dihasilkan suatu aktivitas yang maksimal bila kita tidak mempunyai kebugaran jasmani yang baik. Kebugaran jasmani adalah kemampuan untuk melakukan aktivitas sehari-hari tanpa mengalami kelelahan yang berarti, serta masih memiliki cadangan energi untuk mengisi waktu luang. Sependapat dengan (Deuster \& Silverman, 2013; Walton-Fisette \& Wuest, 2015) mengenai kebugaran jasmani, mereka mengartikan kesegaran jasmani sebagai kemampuan sistem tubuh untuk berfungsi secara efektif dan efisien.

Penilaian kebugaran jasmani seseorang sudah pada level baik atau belum, maka dilakukaknlah suatu tes untuk menilai kebugaran jasmani kita. Bentuk tes kebugaran jasmani yang paling umum digunakan dalam pembelajaran pendidikan jasmani di Indonesia adalah Tes Kebugaran Jasmani Indonesia (TKJI) yang dapat digunakan untuk peserta didik pada tingkat satuan pendidikan dasar dan menengah. TKJI terbagi menjadi empat dengan menggunakan usia sebagai pembeda jenis tes, 6-9 tahun, 10-12 tahun, 13-15 tahun, dan 16-19 tahun serta dibedakan juga berdasarkan jenis kelamin untuk jenis tes pada masing-masing kelompok umur. TKJI sampai sekarang belum ada pembaharuan untuk jenis tes dan prosedur pelaksanaannya. Secara teori kebugaran jasmani terbagi menjadi dua, yaitu: (1) kebugaran jasmani yang berkaitan dengan kesehatan; dan (2) kebugaran jasmani yang berkaitan dengan aspek keterampilan (Pangrazi \& Beighle, 2020). Untuk komponen kebugaran jasmani yang berkaitan dengan kesehatan terdiri dari komposisi tubuh, daya tahan kardiorespirasi, kelentukan, daya tahan otot, dan kekuatan otot. Sedangkan komponen kebugaran jasmani yang berkaitan dengan aspek keterampilan adalah ketangkasan, keseimbangan, koordinasi, kekuatan, kecepatan, dan kecepatan reaksi (Gontarev et al., 2018; Lacy \& Williams, 2018).

TKJI tidak menyebutkan secara spesifik jenis kesegaran jasmani yang diukur apakah kebugaran jasmani yang berkaitan dengan kesehatan ataukah kebugaran jasmani yang berkaitan dengan keterampilan. Guru-guru Pendidikan Jasmani (penjas) 
JURNAL SPORTA SAINTIKA

P-ISSN 2505-5651

E-ISSN 2579-5910

dalam mengukur dan mengevaluasi kebugaran jasmani peserta didik dilakukan dengan cara yang apa adanya, tidak terstandar dengan baik, bahkan memodifikasi alat ukur dengan alasan bahwa sekolah tidak mempunyai sarana prasarana yang standar. Sedangkan data dapat dikatakan benar apabila diperoleh dengan menggunakan alat ukur yang standar, valid, dan reliabel.

Berdasarkan permasalahan tersebut, maka diperlukan standarisasi tes kebugaran jasmani untuk masing-masing komponen dalam mengukur kebugaran jasmani peserta didik. Pada tingkat pendidikan dasar dan menengah, tes kebugaran jasmani yang lazim dilakukan adalah mengukur kebugaran jasmani yang berkaitan dengan kesehatan. Maka tujuan dari penelitian ini adalah untuk mengkaji dan menetapkan alat ukur kebugaran jasmani yang berkaitan dengan kesehatan yang dapat digunakan tidak hanya untuk mengukur dan mengevaluasi kebugaran jasmani peserta didik tetapi harus dapat diterapkan pada jenjang sekolah dasar secara umum.

Dari berbagai literatur dapat kita temukan jenis-jenis alat ukur yang dapat digunakan untuk mengukur masing-masing komponen kebugaran jasmani yang berkaitan dengan kesehatan. Hasil kajian literatur tampak pada tabel 1 di bawah ini:

Tabel 1. Jenis Tes yang Digunakan untuk Masing-Masing Komponen

\begin{tabular}{|c|c|}
\hline Komponen & Jenis Tes yang Dapat Digunakan \\
\hline \multirow[t]{6}{*}{ daya tahan kardiorespirasi } & 20-Meter Multi-Stage Shuttle Run \\
\hline & Yo-Yo Intermittent Recovery Test \\
\hline & Distance-Based Walk and Run Tests \\
\hline & Time-Based Walk or Run Tests \\
\hline & Submaximal Step Test \\
\hline & 45-Second Squat Test \\
\hline \multirow[t]{2}{*}{ komposisi tubuh } & Weight, Height, and Body Mass Index \\
\hline & Skinfold Assessment \\
\hline \multirow[t]{4}{*}{ kelentukan } & Sit-And-Reach Test \\
\hline & Back-Scratch Test \\
\hline & Shoulder Elevation Test \\
\hline & Total Body Rotation Test \\
\hline \multirow[t]{7}{*}{ daya tahan otot } & Prone Bridge (or Plank) \\
\hline & Half-Squat (or Wall-Sit) \\
\hline & Flexed-Arm Hang (or Bent-Arm Hang) \\
\hline & Partial Curl-Ups \\
\hline & Push-Ups \\
\hline & Squats \\
\hline & Pull-Ups \\
\hline kekuatan otot & Maximal Handgrip Strength Test \\
\hline
\end{tabular}


P-ISSN 2505-5651

E-ISSN 2579-5910

(Fukuda, 2019; Lacy \& Williams, 2018; Miller, 2010; Walton-Fisette \& Wuest, 2015)

Dari sekian banyak alat ukur yang dapat digunakan, tentunya tidak semua dapat diterapkan pada sekolah berdasarkan kelengkapan sarana dan prasaran sekolah dan karateriktik peserta didik (disesuaikan dengan usia). Oleh karena itu diperlukan penilaian dari akademisi dan praktisi untuk menetapkan alat ukur mana yang secara konten maupun kontek dapat digunakan dan diterapkan pada anak usia 10-12 tahun untuk mengukur kebugaran jasmani yang berkaitan dengan kesehatan.

\section{METODE}

Metode penelitian yang digunakan adalah metode survei dengan teknik analisis data deskriptif persentase. Purposive accidental sampling digunakan dalam penelitian ini, dimana responden adalah dosen dalam bidang keolahragaan dan guru penjas pada sekolah dasar. Sasaran tersebar secara nasional dengan mengirimkan format penilaian melalui google form, sehingga tidak membatasi pada daerah tertentu atau tingkat pendidikan responden. Data dikumpulkan dalam rentang waktu satu bulan pada bulan September 2020. Analisis data dengan menggunakan bantuan dari aplikasi Ms. Excel.

\section{HASIL PENELITIAN}

Responden yang diterima berjumlah 178 responden, 29 responden adalah dosen dalam bidang keolahragaan, responden guru penjas pada sekolah dasar berjumlah 109 guru, dan sisanya (50 responden) merupakan guru SMP dan SMA.

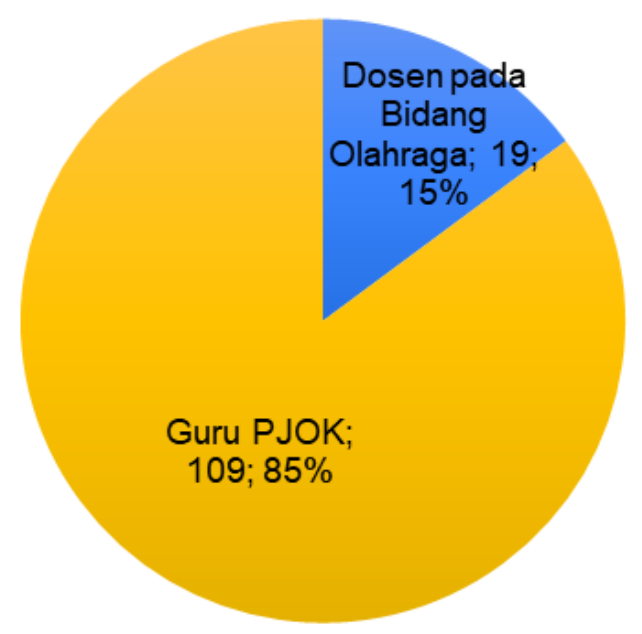

Gambar 1. Responden Penelitian 
Jenis-jenis alat ukur yang tertuang pada tabel 1 sudah pasti dapat digunakan untuk mengukur masing-masing komponen kebugaran yang berkaitan dengan kesehatan. Tetapi apakah dapat diterapkan pada satuan pendidikan dengan target peserta didik dengan usia 10-12 tahun? Hasil survei pada tabel 2 menunjukkan bahwa semua alat ukur tersebut dapat digunakan dan diterapkan untuk mengukur kebugaran jasmani yang berkaitan dengan kesehatan pada peserta didik usia 10-12 tahun.

Tabel 2. Hasil Survei untuk Jenis Alat Tes pada Masing-Masing Komponen

\begin{tabular}{|c|c|c|c|c|c|}
\hline No. & Komponen & \begin{tabular}{|} 
Jenis Tes yang \\
Dapat Digunakan
\end{tabular} & Keputusan & $\begin{array}{l}\text { Jumlah } \\
\text { Respon }\end{array}$ & Persentase \\
\hline \multirow{4}{*}{1} & \multirow{4}{*}{$\begin{array}{l}\text { Komposisi } \\
\text { tubuh }\end{array}$} & \multirow{2}{*}{$\begin{array}{l}\text { Weight, Height, } \\
\text { and Body Mass } \\
\text { Index }\end{array}$} & Dapat diterapkan & 86 & $67,19 \%$ \\
\hline & & & Tidak dapat diterapkan & 42 & $32,81 \%$ \\
\hline & & \multirow{2}{*}{\begin{tabular}{|l|} 
Skinfold \\
Assessment
\end{tabular}} & Dapat diterapkan & 106 & $82,81 \%$ \\
\hline & & & Tidak dapat diterapkan & 22 & $17,19 \%$ \\
\hline \multirow{12}{*}{2} & \multirow{12}{*}{$\begin{array}{l}\text { Daya tahan } \\
\text { kardiorespirasi }\end{array}$} & \multirow{2}{*}{$\begin{array}{l}\text { 20-Meter Multi- } \\
\text { Stage Shuttle Run }\end{array}$} & Dapat diterapkan & 112 & $87,50 \%$ \\
\hline & & & Tidak dapat diterapkan & 16 & $12,50 \%$ \\
\hline & & \multirow{2}{*}{$\begin{array}{l}\text { Yo-Yo Intermittent } \\
\text { Recovery Test }\end{array}$} & Dapat diterapkan & 106 & $82,81 \%$ \\
\hline & & & Tidak dapat diterapkan & 22 & $17,19 \%$ \\
\hline & & \multirow{2}{*}{$\begin{array}{l}\text { Distance-Based } \\
\text { Walk and Run } \\
\text { Tests }\end{array}$} & Dapat diterapkan & 100 & $78,13 \%$ \\
\hline & & & Tidak dapat diterapkan & 28 & $21,88 \%$ \\
\hline & & \multirow{2}{*}{$\begin{array}{l}\text { Time-Based Walk } \\
\text { or Run Tests }\end{array}$} & Dapat diterapkan & 90 & $70,31 \%$ \\
\hline & & & Tidak dapat diterapkan & 38 & $29,69 \%$ \\
\hline & & \multirow{2}{*}{\begin{tabular}{|l} 
Submaximal Step \\
Test
\end{tabular}} & Dapat diterapkan & 115 & $89,84 \%$ \\
\hline & & & Tidak dapat diterapkan & 13 & $10,16 \%$ \\
\hline & & \multirow{2}{*}{\begin{tabular}{|l|}
$45-S e c o n d ~ S q u a t$ \\
Test
\end{tabular}} & Dapat diterapkan & 119 & $92,97 \%$ \\
\hline & & & Tidak dapat diterapkan & 9 & $7,03 \%$ \\
\hline \multirow{6}{*}{3} & \multirow{6}{*}{ Kelentukan } & \multirow{2}{*}{$\begin{array}{l}\text { Sit-And-Reach } \\
\text { Test }\end{array}$} & Dapat diterapkan & 108 & $84,38 \%$ \\
\hline & & & Tidak dapat diterapkan & 20 & $15,63 \%$ \\
\hline & & \multirow{2}{*}{$\begin{array}{l}\text { Shoulder } \\
\text { Elevation Test }\end{array}$} & Dapat diterapkan & 105 & $82,03 \%$ \\
\hline & & & Tidak dapat diterapkan & 23 & $17,97 \%$ \\
\hline & & \multirow{2}{*}{\begin{tabular}{|l|} 
Total Body \\
Rotation Test
\end{tabular}} & Dapat diterapkan & 110 & $85,94 \%$ \\
\hline & & & Tidak dapat diterapkan & 18 & $14,06 \%$ \\
\hline \multirow{8}{*}{4} & \multirow{8}{*}{ Daya tahan otot } & \multirow{2}{*}{$\begin{array}{l}\text { Prone Bridge (or } \\
\text { Plank) }\end{array}$} & Dapat diterapkan & 113 & $88,28 \%$ \\
\hline & & & Tidak dapat diterapkan & 15 & $11,72 \%$ \\
\hline & & \multirow{2}{*}{$\begin{array}{l}\text { Half-Squat (or } \\
\text { Wall-Sit) }\end{array}$} & Dapat diterapkan & 124 & $96,88 \%$ \\
\hline & & & Tidak dapat diterapkan & 4 & $3,13 \%$ \\
\hline & & \multirow{2}{*}{$\begin{array}{l}\text { Flexed-Arm Hang } \\
\text { (or Bent-Arm } \\
\text { Hang) }\end{array}$} & Dapat diterapkan & 80 & $62,50 \%$ \\
\hline & & & Tidak dapat diterapkan & 48 & $37,50 \%$ \\
\hline & & \multirow{2}{*}{ Partial Curl-Ups } & Dapat diterapkan & 119 & $92,97 \%$ \\
\hline & & & Tidak dapat diterapkan & 9 & $7,03 \%$ \\
\hline
\end{tabular}




\begin{tabular}{|c|c|c|c|c|c|}
\hline No. & Komponen & \begin{tabular}{|c|} 
Jenis Tes yang \\
Dapat Digunakan
\end{tabular} & Keputusan & $\begin{array}{l}\text { Jumlah } \\
\text { Respon }\end{array}$ & Persentase \\
\hline & & & Dapat diterapkan & 118 & $92,19 \%$ \\
\hline & & Push-Ups & Tidak dapat diterapkan & 10 & $7,81 \%$ \\
\hline & & Scuratc & Dapat diterapkan & 119 & $92,97 \%$ \\
\hline & & oquals & Tidak dapat diterapkan & 9 & $7,03 \%$ \\
\hline & & $P_{1}$ & Dapat diterapkan & 86 & $67,19 \%$ \\
\hline & & $P U$ & Tidak dapat diterapkan & 42 & $32,81 \%$ \\
\hline \multirow{2}{*}{5} & \multirow{2}{*}{ Kekuatan otot } & Maximal Handgrip & Dapat diterapkan & 67 & $52,34 \%$ \\
\hline & & Strength Test & Tidak dapat diterapkan & 61 & $47,66 \%$ \\
\hline
\end{tabular}

Selanjutnya adalah melakukan penilaian untuk mendapatkan hasil dari alat ukur mana yang mendapatkan prosentase pemilihan dari responden untuk dapat diterapkan pada sekolah dasar (SD) dengan tingkat kelengkapan sarana dan prasarana yang tidak merata antara sekolah satu dengan sekolah lainnya. Hasil dari pemilihan alat tes yang dapat diterapkan di sekolah untuk masing-masing komponen tampak pada tabel 3.

Tabel 3. Pemilihan Jenis Tes yang Dapat Diterapkan pada Sekolah

\begin{tabular}{|c|c|c|c|c|}
\hline No. & Komponen & Jenis Tes & Respon & Prosentase \\
\hline \multirow[t]{2}{*}{1} & \multirow[t]{2}{*}{$\begin{array}{l}\text { Komposisi } \\
\text { Tubuh }\end{array}$} & $\begin{array}{l}\text { Weight, Height, and Body Mass } \\
\text { Index }\end{array}$ & 128 & $100 \%$ \\
\hline & & Skinfold Assessment & 6 & $4,69 \%$ \\
\hline \multirow[t]{6}{*}{2} & \multirow{6}{*}{$\begin{array}{l}\text { Daya Tahan } \\
\text { Kardiorespir } \\
\text { asi }\end{array}$} & 20-Meter Multi-Stage Shuttle Run & 97 & $75,78 \%$ \\
\hline & & Yo-Yo Intermittent Recovery Test & 40 & $31,25 \%$ \\
\hline & & $\begin{array}{l}\text { Distance-Based Walk and Run } \\
\text { Tests }\end{array}$ & 44 & $34,38 \%$ \\
\hline & & Time-Based Walk or Run Tests & 40 & $31,25 \%$ \\
\hline & & Submaximal Step Test & 62 & $48,44 \%$ \\
\hline & & 45-Secondsquats Test & 79 & $61,72 \%$ \\
\hline \multirow[t]{4}{*}{3} & \multirow[t]{4}{*}{ Kelentukan } & Sit-and-Reach Test & 100 & $78,13 \%$ \\
\hline & & Back-Scratch Test & 78 & $60,94 \%$ \\
\hline & & Shoulder Elevation Test & 36 & $28,13 \%$ \\
\hline & & Total Body Rotation Test & 39 & $30,47 \%$ \\
\hline \multirow[t]{7}{*}{4} & \multirow{7}{*}{$\begin{array}{l}\text { Daya Tahan } \\
\text { Otot }\end{array}$} & Prone Bridge (or Plank) & 79 & $61,72 \%$ \\
\hline & & Half-Squats (or Wall-Sit) & 73 & $57,03 \%$ \\
\hline & & $\begin{array}{l}\text { Flexed-Arm Hang (or Bent-Arm } \\
\text { Hang) }\end{array}$ & 45 & $35,16 \%$ \\
\hline & & Partial Curl-Ups & 38 & $29,69 \%$ \\
\hline & & Push-Ups & 93 & $72,66 \%$ \\
\hline & & Squats & 67 & $52,34 \%$ \\
\hline & & Pull-Ups & 34 & $26,56 \%$ \\
\hline \multirow[t]{3}{*}{5} & \multirow{3}{*}{$\begin{array}{l}\text { Kekuatan } \\
\text { Otot } \\
\text { (Maximal } \\
\text { Handgrip } \\
\text { Strength }\end{array}$} & $\mathrm{Ya}$ & 80 & $62,50 \%$ \\
\hline & & Tidak & 40 & $31,25 \%$ \\
\hline & & Lainnya & 8 & $6,25 \%$ \\
\hline & (2) & & $\begin{array}{l}\text { lume } \\
\text { spor }\end{array}$ & $\begin{array}{l}\text { mor } 1, \mathrm{~N} \\
\text { intika.pp }\end{array}$ \\
\hline
\end{tabular}


JURNAL SPORTA SAINTIKA

P-ISSN 2505-5651

E-ISSN 2579-5910

\begin{tabular}{|c|c|c|c|c|}
\hline No. & Komponen & Jenis Tes & Respon & Prosentase \\
\hline & Test) & & & \\
\hline
\end{tabular}

Dari hasil pemilihan alat tes yang telah dilakukan, maka dapat ditentukan alat tes untuk masing-masing komponen yang dapat digunakan pada sebagaian besar satuan pendidikan dasar dengan sasaran peserta didik usia 10-12 tahun.

Tabel 4. Hasil Penentuan Alat Tes

\begin{tabular}{|c|l|l|}
\hline No. & \multicolumn{1}{|c|}{ Komponen } & \multicolumn{1}{c|}{ Jenis Tes } \\
\hline $\mathbf{1}$ & Komposisi tubuh & Weight, Height, and Body Mass Index \\
\hline $\mathbf{2}$ & Daya tahan kardiorespirasi & 20-Meter Multi-Stage Shuttle Run \\
\hline $\mathbf{3}$ & Kelentukan & Sit-and-Reach Test \\
\hline $\mathbf{4}$ & Daya tahan otot & Push-Ups \\
\hline $\mathbf{5}$ & Kekuatan otot & Maximal Handgrip Strength Test \\
\hline
\end{tabular}

Tabel 4 menunjukkan variabel kebugaran jasmani yang berkaitan dengan kesehatan dapat diukur dengan alat tes yang disepakati oleh sebagian besar responden (guru dan praktisi pendidikan jasmani) dapat diterapkan pada satuan pendidikan dasar dengan memperhatikan karaktristik peserta didik, sarana dan prasarana sekolah, serta kemampuan guru penjas dalam malakukan tes kebugaran jasmani di sekolah.

\section{PEMBAHASAN}

Komposisi tubuh merupakan gambaran tubuh dalam istilah otot, tulang, lemak, dan elemen lainnya. Berkenaan dengan kebugaran jasmani yang berkaitan dengan kesehatan, ini mengacu pada persentase berat badan yang terdiri dari lemak dibandingkan dengan jaringan bebas lemak atau tanpa lemak. Selama beberapa tahun terakhir, Indeks Massa Tubuh (IMT) telah menjadi penilaian utama untuk mengidentifikasi apakah seseorang kekurangan berat badan, normal, kelebihan berat badan, atau obesitas (Cote et al., 2013; Stienen et al., 2019). Indeks ditentukan dengan rumus sebagai berikut: Berat badan $(\mathrm{kg}) /$ Tinggi badan $(\mathrm{m})^{2}$ (MacMahon et al., 2009). Alat yang dibutuhkan adalah timbangan berat badan skala digital dan stadiometer (alat pengukur tinggi badan) berbasis dinding atau berdiri bebas.

Metode terbaik untuk menentukan tingkat fungsi kardiorespirasi adalah dengan mengukur konsumsi oksigen maksimal. Semakin banyak oksigen yang dapat dikirim dan digunakan oleh tubuh, semakin banyak pekerjaan yang dapat dilakukan tubuh sebelum terjadi kelelahan. Konsumsi oksigen maksimal adalah tingkat terbesar di mana oksigen diproses dan digunakan oleh tubuh (Bento-Torres et al., 2019). Ada berbagai metode lain yang bisa dilakukan digunakan untuk memberikan perkiraan 
P-ISSN 2505-5651

E-ISSN 2579-5910

yang baik tentang daya tahan jantung. Tes yang paling umum digunakan adalah lari/jalan kaki berjangka waktu dan atau jarak, dan tes Pacer (untuk anak-anak dan remaja) (Canepa et al., 2020). Tes ini paling sering digunakan di sekolah dan program kebugaran komunitas. Apabila tes ini dilakukan dengan benar, hasilnya dapat digunakan untuk memperkirakan secara akurat konsumsi oksigen maksimal dan memberikan indikator kebugaran kardiorespirasi.

Fleksibilitas dapat didefinisikan sebagai rentang gerak maksimum yang memungkinkan untuk digerakkan pada suatu sambungan yaitu, tingkat pergerakan yang mungkin terjadi di sekitar sambungan tanpa ketegangan yang tidak semestinya. Walaupun merupakan salah satu komponen fitnes yang paling penting, namun sering kali diabaikan, dan akibatnya perkembangannya terabaikan. Karena fleksibilitas bersifat spesifik sendi, tidak ada satu pengujian pun yang dapat digunakan untuk memberikan ukuran keseluruhan dari fleksibilitas individu. Ada tes yang telah dikembangkan untuk mengukur gerakan pada sendi tertentu dan hanya membutuhkan sedikit peralatan untuk melakukannya. Misalnya, tes sit and reach digunakan untuk menilai kelenturan otot punggung bawah dan hamstring.

Kekuatan otot adalah kemampuan suatu otot atau kelompok otot untuk mengerahkan tenaga secara berulang-ulang dikenal sebagai daya tahan otot. Daya tahan otot juga mengacu pada kapasitas otot atau kelompok otot untuk menopang keadaan kontraktif selama periode waktu tertentu. Otot yang berbeda dalam tubuh dapat memiliki tingkat kekuatan dan daya tahan yang berbeda. Bahkan, otot yang digunakan lebih sering lebih kuat dan memiliki daya tahan lebih besar daripada otot yang jarang digunakan. Ketika otot tidak digunakan, kekuatan dan daya tahan menurun. Kekuatan dapat diukur secara isometrik dengan menggunakan dinamometer. Saat kontraksi otot terjadi, gaya ditransmisikan ke alat ukur dan dapat direkam (misalnya, dinamometer tangan dapat digunakan untuk menentukan kekuatan cengkeraman). Daya tahan juga dapat ditentukan dengan mengukur waktu kontraksi tertentu yang dapat dipertahankan (misalnya, berapa lama push-up statis dapat ditahan).

Di dunia ini ada lebih dari 15 rangkaian tes untuk menilai kebugaran jasmani anak-anak dan remaja dan beberapa komponen penting dari kebugaran jasmani yang digunakan pada saat ini (Castro-Piñero et al., 2010). Pada beberapa negara di Eropa menggunakan rangkaian tes EUROFIT (6-18 tahun) di sekolah dan Amerika Serikat 
JURNAL SPORTA SAINTIKA

P-ISSN 2505-5651

E-ISSN 2579-5910

menggunakan rangkaian tes FITNESSGRAM (5-17 tahun), di Indonesia menggunakan TKJI (Tes Kesegaran Jasmani Indonesia) yang terbagi dengan rentang usia 6-9 tahun, 10-12 tahun, 13-15 tahaun, dan 16-19 tahun, sedangkan dari penelitian ini dihasilkan sebuah battery test kebugaran jasmani untuk usia 10-12 tahun yang dapat dilakukan oleh satuan pendidikan dasar di Indonesia dengan memperhatikan karakteristik peserta didik, kelengkapan sarana dan prasaran satuan pendidikan tersebut, dan kemampuan guru penjas dalam mengorganisir tes kebugaran jasmani. Tujuan penilaian kebugaran jasmani peserta didik pada pembelajaran pendidikan jasmani menjadi topik yang selalu diperbincangkan dengan masing-masing pendapatnya (Lloyd et al., 2010), karena usulan utamanya adalah evaluasi kebugaran jasmani yang berkaitan dengan kesehatan sebagai bagian dari proses pendidikan jasmani pada khususnya dan kesehatan secara keseluruhan (Csányi et al., 2015).

Tanpa mengkesampingkan kebugaran jasmani yang berkaitan dengan keterampilan, tes kebugaran jasmani yang sering dilakukan oleh guru penjas dalam mengevaluasi kebugaran jasmani peserta didik adalah kebugaran jasmani yang berkaitan dengan kesehatan, yang terdiri dari variabel komposisi tubuh, daya tahan kardiovaskular, kekuatan otot, daya tahan otot, dan fleksibilitas (Castro-Piñero et al., 2010; Keating et al., 2018) dan karena integrasi antara kebugaran jasmani dan kurikulum pendidikan jasmani adalah bagian penting dalam pendidikan kesehatan pada umumnya (Cohen et al., 2015; Pate et al., 2013; Vazou et al., 2019). Strategi untuk melakukan tes kebugaran jasmani dalam lima tahun terakhir sudah berkembang dengan pesat dan baik (Lester, 2015; Youm et al., 2015; Zhu et al., 2018), yaitu penggunaan teknologi yang lebih praktis, efektif, dan efisien sebagai bagian dari evaluasi kebugaran jasmani peserta didik.

Kebugaran jasmani merupakan salah satu indikator untuk memprediksi gaya hidup sehat dan aktif. Kebugaran jasmani adalah kemampuan seseorang untuk melakukan aktivitas sehari-hari tanpa kelelahan fisik yang berarti dan cedera yang menyertainya, serta kemampuan untuk menjaga level tertinggi dari penggunaan energi untuk beraktivitas sehari-hari. Kebugaran jasmani merupakan salah satu komponen penting sebagai indikator kesehatan dan perilaku hidup sehat bagi anak pada usia sekolah yang mempunyai manfaat positif antara lain dapat meningkatkan fungsi organ tubuh, meningkatkan kemampuan kognitif, memupuk sportivitas, dan 
JURNAL SPORTA SAINTIKA

P-ISSN 2505-5651

E-ISSN 2579-5910

mengobarkan semangat kompetisi. Bahkan beberapa penelitian menyebutkan bahwa kebugaran jasmani mempunyai hubungan positif dengan prestasi akademik (Bayu et al., 2021; Bayu \& Hasmara, 2018; Donnelly et al., 2016; Seljebotn et al., 2019). Selain itu, tingkat kebugaran jasmani yang baik tidak hanya bermanfaat untuk memelihara kondisi tubuh yang sehat, tetapi juga untuk proses penyembuhan tubuh yang tidak sehat.

\section{KESIMPULAN}

Dari hasil penelitian ini dapat ditentukan jenis tes untuk masing-masing komponen kebugaran jasmani yang berkaitan dengan kesehatan yang terdiri dari lima jenis tes untuk mengukur lima indikator dalam kebugaran jasmani yang berkaitan dengan kesehatan. Lima variabel kebugaran jasmani tersebut adalah komposisi tubuh dengan tes weight, height, and body mass index, daya tahan kardiorespirasi dengan tes 20-meter multi-stage shuttle run, kelentukan dengan sit-and-reach test, daya tahan otot dengan tes push-ups, dan kekuatan otot dengan maximal handgrip strength test. Untuk penelitian selanjutnya dapat dilakukan ujicoba untuk mendapatkan data akurat untuk pengukuran kebugaran jasmani usia 10-12 tahun. Dengan kondisi pandemi COVID-19 dan perkembangan teknologi dalam proses pembelajaran terutama dalam hal evaluasi, maka dapat diterapkan self-testing untuk mendapatkan data apakah alat ukur kebugaran jasmani ini memang dapat diterapkan kepada peserta didik.

\section{UCAPAN TERIMA KASIH}

Terima kasih kepada Universitas Sriwijaya karena telah mendanai penelitiain ini. Penelitian ini didanai dengan Anggaran DIPA Badan Layanan Umum Universitas Sriwijaya Tahun Anggaran 2020 No. SP DIPA-023.17.2.677515/2020, Revisi ke 01 tanggal 16 Maret 2020 sesuai dengan SK Rektor Nomor: 0684/UN9/SK.BUK.KP/2020 Tanggal 15 Juli 2020.

\section{DAFTAR PUSTAKA}

Bayu, W. I., Destriana, Victorian, A. R., Yusfi, H., \& Solahuddin, S. (2021). Fitness level effect on the Grade-Point Average of Physical Education Major Students. Halaman Olahraga Nusantara (Jurnal IImu Keolahragaan), 4(2), 180-191. https://doi.org/10.31851/hon.v4i2.5239

Bayu, W. I., \& Hasmara, P. S. (2018). The Relationship between Physical Fitness and Academic Achievement in Physical Education, Sport, and Health. 1(Icsshpe 2017), 124-128. https://doi.org/10.5220/0007056301240128 
Bento-Torres, J., Bento-Torres, N. V. O., Stillman, C. M., Grove, G. A., Huang, H., Uyar, F., Watt, J. C., Wollam, M. E., \& Erickson, K. I. (2019). Associations between cardiorespiratory fitness, physical activity, intraindividual variability in behavior, and cingulate cortex in younger adults. Journal of Sport and Health Science, 8(4), 315324. https://doi.org/10.1016/j.jshs.2019.03.004

Canepa, P., Pedullà, L., Bisio, A., Ruggeri, P., \& Bove, M. (2020). Is the 12 minutewalk/run test a predictive index of cognitive fitness in young healthy individuals? A pilot study on aerobic capacity and working memory in a real-life scenario. $\begin{array}{lll}\text { Neuroscience } \quad \text { Letters, } & \text { 728(April), }\end{array}$ https://doi.org/10.1016/j.neulet.2020.134983

Castro-Piñero, J., Artero, E. G., España-Romero, V., Ortega, F. B., Sjöström, M., Suni, J., \& Ruiz, J. R. (2010). Criterion-related validity of field-based fitness tests in youth: A systematic review. British Journal of Sports Medicine, 44(13), 934-943. https://doi.org/10.1136/bjsm.2009.058321

Cohen, D. D., Voss, C., \& Sandercock, G. R. H. (2015). Fitness testing for children: Let's mount the zebra! Journal of Physical Activity and Health, 12(5), 597-603. https://doi.org/10.1123/jpah.2013-0345

Cote, A. T., Harris, K. C., Panagiotopoulos, C., Sandor, G. G. S., \& Devlin, A. M. (2013). Childhood obesity and cardiovascular dysfunction. Journal of the American College of Cardiology, 62(15), 1309-1319. https://doi.org/10.1016/j.jacc.2013.07.042

Csányi, T., Finn, K. J., Welk, G. J., Zhu, W., Karsai, I., Ihász, F., Vass, Z., \& Molnár, L. (2015). Overview of the Hungarian national youth fitness study. Research Quarterly for Exercise and Sport, 86(sup1), S3-S12. https://doi.org/10.1080/02701367.2015.1042823

Deuster, P. A., \& Silverman, M. N. (2013). Physical fitness: A pathway to health and resilience. U.S. Army Medical Department Journal, 24-35. https://www.researchgate.net/publication/258065513_Physical_fitness_A_pathway_t o_health_and_resilience

Donnelly, J. E., Hillman, C. H., Castelli, D., Etnier, J. L., Lee, S., Tomporowski, P., Lambourne, K., \& Szabo-Reed, A. N. (2016). Physical activity, fitness, cognitive function, and academic achievement in children: A systematic review. Medicine and Science in Sports and Exercise, 48(6), 1197-1222. https://doi.org/10.1249/MSS.0000000000000901

Fukuda, D. H. (2019). Assessments for Sport and Athletic Performance. Human Kinetics Publishers Inc.

Gontarev, S., Kalac, R., Velickovska, L. A., Stojmanovska, D. S., Misovski, A., \& Milenkovski, J. (2018). Health-related physical fitness of normal, stunted and overweight children aged 6-14 years in Macedonia. Nutricion Hospitalaria, 35(5), 1208-1214. https://doi.org/10.20960/nh.1794

Keating, X. D., Smolianov, P., Liu, X., Castro-Piñero, J., \& Smith, J. (2018). Youth Fitness Testing Practices: Global Trends and New Development. Sport Journal. https://thesportjournal.org/article/youth-fitness-testing-practices-global-trends-andnew-development/

Lacy, A. C., \& Williams, S. M. (2018). Measurement and Evaluation in Physical Education and Exercise Science. In Measurement and Evaluation in Physical Education and 


\section{Exercise Science. Routledge. https://doi.org/10.4324/9781315312736}

Lester, J. (2015). Using Technology for Alternative Assessment in Health Education. Journal of Physical Education, Recreation \& Dance, 86(9), 50-52. https://doi.org/10.1080/07303084.2015.1086611

Lloyd, M., Colley, R. C., \& Tremblay, M. S. (2010). Advancing the debate on "fitness testing" for children: Perhaps we're riding the wrong animal. In Pediatric Exercise Science (Vol. 22, Issue 2, pp. 176-182). Human Kinetics Publishers Inc. https://doi.org/10.1123/pes.22.2.176

MacMahon, S., Baigent, C., Duffy, S., Rodgers, A., Tominaga, S., Chambless, L., De Backer, G., De Bacquer, D., Kornitzer, M., Whincup, P., Wannamethee, S. G., Morris, R., Wald, N., Morris, J., Law, M., Knuiman, M., Bartholomew, H., Davey Smith, G., Sweetnam, P., ... Whitlock, G. (2009). Body-mass index and causespecific mortality in 900000 adults: Collaborative analyses of 57 prospective studies. The Lancet, 373(9669), 1083-1096. https://doi.org/10.1016/S01406736(09)60318-4

Miller, D. K. (2010). Measurement by the Physical Educator:Why and How (6th edition). McGraw-Hill Education. https://www.amazon.com/Measurement-Physical-EducatorHardcover/dp/B004PG825U

Pangrazi, R. P., \& Beighle, A. (2020). Dynamic Physical Education for Elementary School Children (19th Edition). Human Kinetics.

Pate, R. R., Welk, G. J., \& Mclver, K. L. (2013). Large-scale youth physical fitness testing in the United States: A 25-year retrospective review. Pediatric Exercise Science, 25(4), 515-523. https://doi.org/10.1123/pes.25.4.515

Seljebotn, P. H., Skage, I., Riskedal, A., Olsen, M., Kvalø, S. E., \& Dyrstad, S. M. (2019). Physically active academic lessons and effect on physical activity and aerobic fitness. The Active School study: A cluster randomized controlled trial. Preventive Medicine Reports, 13(October 2018), 183-188. https://doi.org/10.1016/j.pmedr.2018.12.009

Stienen, S., Ferreira, J. P., Girerd, N., Duarte, K., Lamiral, Z., McMurray, J. J. V., Pitt, B., Dickstein, K., Zannad, F., \& Rossignol, P. (2019). Mean BMI, visit-to-visit BMI variability and BMI changes during follow-up in patients with acute myocardial infarction with systolic dysfunction and/or heart failure: insights from the High-Risk Myocardial Infarction Initiative. Clinical Research in Cardiology, 108(11), 12151225. https://doi.org/10.1007/s00392-019-01453-7

Vazou, S., Mischo, A., Ladwig, M. A., Ekkekakis, P., \& Welk, G. (2019). Psychologically informed physical fitness practice in schools: A field experiment. Psychology of Sport and Exercise, 40, 143-151. https://doi.org/10.1016/j.psychsport.2018.10.008

Walton-Fisette, J. L., \& Wuest, D. A. (2015). Foundations of Physical Education, Exercise Science, and Sport. In McGraw-Hill Education (19th ed.). McGraw-Hill Education.

Youm, S., Jeon, Y., Park, S. H., \& Zhu, W. (2015). RFID-based automatic scoring system for physical fitness testing. IEEE Systems Journal, 9(2), 326-334. https://doi.org/10.1109/JSYST.2013.2279570

Zhu, X., Davis, S., Kirk, T. N., Haegele, J. A., \& Knott, S. E. (2018). Inappropriate Practices in Fitness Testing and Reporting: Alternative Strategies. Journal of Physical Education, Recreation and Dance, 89(3), 46-51.

\begin{tabular}{rr}
\hline (c) () & Volume 6, Nomor 1, Maret 2021 \\
sportasaintika.ppj.unp.ac.id
\end{tabular}


JURNAL SPORTA SAINTIKA

P-ISSN 2505-5651

E-ISSN 2579-5910

https://doi.org/10.1080/07303084.2017.1417929 